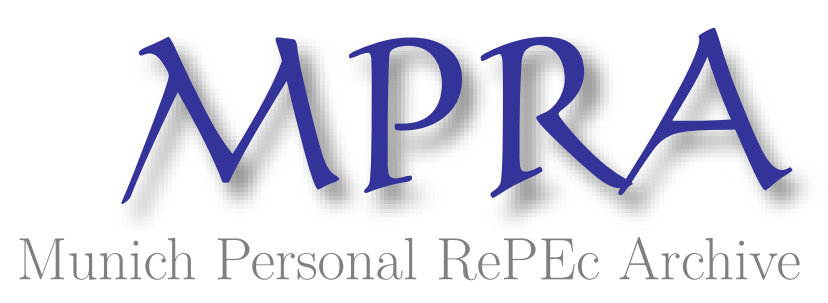

Earnings Management in Interconnected
Networks: A Perspective

Ozili, Peterson K

2017

Online at https://mpra.ub.uni-muenchen.de/92647/

MPRA Paper No. 92647, posted 11 Mar 2019 13:25 UTC 


\title{
Earnings Management in Interconnected Networks: A Perspective
}

\author{
Peterson K Ozili \\ Essex Business School, Essex University \\ United Kingdom
}

2017

\begin{abstract}
This article examine how firms manage earnings when firms are in interconnected networks, that is, when firms are interconnected to each other in a way that the survival of one firm is crucial to the survival of other firms connected to it. The article employs network typology to provide some insight on the earnings management behaviour of firms in regulated and unregulated networks or systems. We find that firms in the inner core of interconnected networks are more likely to rely on income smoothing behaviour as a preferred form of earnings management because it stabilizes the firm's link with other firms in the network. In regulated networks, we propose a negative relationship between a firm's network centrality and the number of earnings management strategies the manager can adopt. Also, we propose a positive relationship between a firm's network centrality and the propensity to smooth earnings or income when firms are concerned about their reputation or regulatory scrutiny. This article is a brief note on earnings management, and an attempt provide a perspective on how earnings management can be explained using a network typology.
\end{abstract}

Keywords: Financial Network, Earnings Management, Income Smoothing, Systemic Risk, Contagion, Network Fragility, Regulation, Reputation, Accounting Quality, Financial Institutions

To cite: Ozili, P. K. (2017). Earnings management in interconnected networks: a perspective. Journal of Economic and Administrative Sciences, 33(2), 150-163. 


\section{Introduction}

We explore earnings management among interconnected firms to provide insights on how firms might manage earnings when they are interconnected by networks. By interconnections, we mean firms that are interconnected with each other in a way that the survival of one firm is crucial to the survival of other firms connected to it. A real-life example would be the case of banks in the global banking system. Banks became interconnected to each other long before the 2007-2008 financial crisis, and were also connected to large non-financial firms that depended on banks. After the financial crisis, national and global bank supervisors now think of banks and banking supervision in terms of 'networks' or 'financial networks' or 'interconnectedness' (Haldane, 2013). This idea that firms exist in highly interconnected and complex networks led to the emergence of studies that investigate the characteristics and behaviour of firms that are interconnected by financial networks.

Indeed, serious concern for financial instability in several countries have also led to a boom of papers on financial networks to improve financial stability. One of the major concerns in these debates is systemic risk, and network typology has been used to understand systemic risk (Allen and Gale, 2000; Markose, 2012; Battiston et al, 2012). Yet, little is known about the network typology of similar financial reporting practices between firms which can contribute to systemic risk, and little is also known about how similar accounting choice by connected firms contribute to propagate network-style contagion, leading to systemic risk. To the best of our knowledge, the network topology of earnings management in financial reporting has so far not been studied.

Our study applies the idea of networks to propose and develop a framework that explains the earnings management behaviour of firms when firms are part of an interconnected network. We build on network topology from the financial network literature to develop a framework that explains the earnings management behaviour of firms when firms are part of a fragile and complex financial network. So far, there is much evidence that firms manage reported earnings to meet several financial reporting objectives (e.g. Bouvatier et al, 2014; Cohen et al, 2014; Ozili, 2017), however, it is not clear how firms manage earnings when firms are considered to be interconnected. There is scant knowledge on network-based approach to understand earnings management particularly among interconnected firms, therefore, our discussion in this paper contributes to the earnings management literature by showing how a network perspective of accounting choice can provide insights to understand the earnings management behaviour of interconnected firms. We provide a perspective and conclude that firms in the core periphery of highlyinterconnected (or complex) networks are more likely to engage in income smoothing as a type of earnings management behaviour relative to firms in the outer periphery in the network, and this behaviour varies with the network-centrality of firms in the network.

Our contribution to the literature is two-fold. First, our discussion in this article contribute to the financial network literature by providing insights on the financial reporting behaviour of firms in financial networks. We point out that the earnings management behaviour of firms in connected networks will be driven by firms' knowledge of their position in the network. Secondly, our study contributes to the earnings management literature by providing another way to think about earnings management among interconnected firms. Finally, we are aware that accounting standard-setters want to understand the earnings management practices of systemic or 'highly-interconnected' firms. Insights from the framework developed in this paper can guide and inform future standard-setting policies on the financial reporting practices of systemic financial and non-financial institutions. 
The remainder of this chapter is organised as follows. Section 2 presents the literature review on networks and earnings management. Section 3 provides a conceptual framework on networks. Section 4 develops the network-based earnings management framework. Section 5 concludes. Throughout the paper, we use the term 'income smoothing', 'profit smoothing' and 'earnings smoothing' interchangeably to mean the same thing.

\section{Literature Review}

\subsection{Networks}

Network typology has been used to describe modern real-world financial systems in the literature. For instance, Boss et al (2004) use network topology to examine the Austrian interbank market. Nagurney and $\mathrm{Ke}$ (2001) examine financial networks in financial intermediation. Boginski et al (2005) applied network analysis to stock markets. Iori et al (2008) applied the concept of networks to describe the Italian overnight money market and find evidence for increasing network-interconnectedness but decreasing network strength while Haldane (2013) provides a characterisation of the world's financial network. Markose (2012) use financial network typology to provide a firm level bottom-up holistic visualization of the interconnection of financial obligations in global OTC derivatives market.

In the theoretical literature, financial networks are considered to be beneficial for risk-sharing and/or losssharing among interconnected firms although they also facilitate the propagation of contagion. For instance, Allen and Gale (2000) investigate the resilience to shocks in a stylized four-bank network. They sought to understand how banking systems respond to contagion when banks are interconnected under different network structures. They demonstrate that complete networks, in which every bank is connected to every other bank, are more resilient due to risk-sharing among firms (or agents) while incomplete networks, in which every bank is connected with fewer than all banks, are more fragile; therefore, lessinterconnected banks will have difficulty to absorb shocks to the financial system

Nier et al (2007) investigate the resilience of financial networks to shocks and find that contagious bank defaults spreads in highly interconnected bank networks. They also observe that at small levels of connectivity, a small increase in interconnectedness increases the likelihood of contagion while higher connectivity in more connected networks improves the ability of the financial system to absorb shocks through risk-sharing. Gai and Kapadia (2010) show that the likelihood of contagion in less-interconnected networks is low but when events that initiates the propagation of contagion sets in, the impact can be widespread. Interestingly, they observe that aggregate shocks will have different impact on the financial system depending on the importance of the affected nodes (banks) in the financial network. This means that a shock that affects a highly connected bank will have serious consequences on the overall system compared to the same shock that affects a less connected bank. Amini et al (2016) show that institutions which contribute most to network instability have both large interconnections and a large fraction of contagious links. Acemoglu et al (2013) find that although complete networks are generally more stable under extreme conditions, the high number of interconnections are responsible for higher fragility in financial networks. Sachs (2014) use simulation approach to investigate the impact of the structure of the matrix of interbank liabilities on financial stability ${ }^{1}$, and find that financial stability depends on both the

\footnotetext{
${ }^{1}$ Sachs (2014) characterised the financial system according to the number of banks, total assets in the banking
} 
completeness of the network, the interconnectedness of the network and the distribution of interbank exposures within the system, that is, the distribution of financial claims within the system. Leitner (2005) applied financial networks to design an optimal financial network that minimise the trade-off between risk-sharing and the contagion (that is, the potential for collapse) in relation to investment decisions of a firm. ${ }^{2}$ Interestingly, Leitner (2005)'s model show that financial networks (linkages or interconnections) are desirable when they act as channels for contagion because they can motivate banks to bail-out each other if banks can coordinate to do so when contagion arises. While Leitner (2005)'s argument that banks can bail-out each other is interesting, it is important to stress that a bank will bail-out other banks only when the bank itself is not under financial distress, implying that a bank will rationally save itself first before saving another bank. Battiston et al (2012) investigate the association between interconnectedness and systemic risk in a model of the economy as a credit network. They show that although higher interconnections improve risk-sharing, it also amplifies the current economic recession or boom. ${ }^{3}$ Acharya and Richardson (2009) oppose risk-sharing emanating from systemic firms, and rather argue that systemic banks should internalize the risk they pose to the financial system. Acemoglu et al (2015) examine the relationship between the financial network architecture and the likelihood of systemic failures due to contagion of counterparty risk. They show that as long as the magnitude and the number of negative shocks affecting financial institutions are sufficiently small, more complete interconnections (i.e. interbank claims) will enhance stability in the system up at a certain point beyond which such interconnections start to serve as a mechanism to propagate shocks which leads to a more fragile financial system.

Furthermore, Castiglionesi and Navarro (2008) develop a model to study the endogenous formation of a financial network or banking network, and find that banks voluntarily form networks among themselves because it allows them to co-insure future and uncertain liquidity needs, implying that financial networks provide liquidity co-insurance for connected banks because it represent the lines of credit that banks grant to each other. ${ }^{4}$ Afonso et al (2011) also stress that, when the risk associated with the lending of funds is too high, interconnections become too costly compared to the benefits they bring and safe banks will sever their financial links to eliminate troubled banks so that safe banks will continue to be linked to, and insure, other safe banks. Also, Gofman (2017) show that during crisis periods, stability in financial networks can be improved with higher liquidity requirements and when failed banks' depositors maintain confidence in the banking system. Cabrales et al (2015) show that in financial networks, contagion spreads if a shock to one market is transmitted to other markets due to information revealed in the first market. They show that financial contagion depends not only on the network structure but also on firms' knowledge and beliefs about the network structure.

\subsection{Earnings Management}

system, equity ratio, the ratio of interbank to total assets and loss given default;

22 Leitner construct a model where the success of an agent's investment in a project depends on the investments of other agents linked to the agent's project. Leitner was particularly interested to design an optimal financial networks that minimise the trade-off between risk-sharing and contagion (that is, the potential for collapse). ${ }^{3}$ Battiston et al. (2012) explain that when an economic agent suffers a negative shock, counterparties to the economic agent react by withdrawing from existing trade deals or refusing to engage in trade deals with the economic agent. This further makes economic conditions harder for the economic agent, hence, financial fragility amplifies the current state of agents in the economy

${ }^{4}$ While interconnections provide liquidity insurance among connected firms, it also creates counterparty risk 
The earnings management literature, on the other hand, show that firms can manipulate reported earnings using accrual and real techniques or a combination of both techniques (Gunny, 2005; Zang, 2011) and the components of accruals that is manipulated vary by firm context and in predictable ways for firms in some industries (Marquardt and Wiedman, 2004). Firms use a combination of accrual or real techniques to manage reported earnings to: avoid reporting a loss or loss avoidance ( Burgstahler and Dichev, 1997; DeGeorge et al., 1999); to engage in income-increasing earnings management (Rangan, 1998; Barth et al., 1999), to smooth reported earnings over time (LapointeAntunes et al., 2006; Ozili, 2015 \& 2017), amongst others. Given the portfolio of earnings management strategies available to managers in industrial and financial firms, the common accounting procedures (and accounting numbers) used to manage earnings include: changes to pension assumptions, inventory methods, depreciation method and estimates (Sweeney, 1994); available-for-sale securities (Barth et al., 2016); loan loss provisions (Ozili, 2015, 2017); gains from the timing of asset sales (Hermann et al., 2003); pension costs (Bergstresser and Phillipon, 2006); reduction in advertising and R\&D expense (Gunny, 2005; Cohen et al., 2010); use of sales discounts (Roychowdhury, 2006); inventory overproduction (Thomas and Zhang, 2002; Roychowdhury, 2006); stock repurchase (Hribar et al., 2006); derivative hedging (Barton, 2001; Pincus and Rajgopal, 2002); and securitization (Dechow and Shakespeare, 2009; Dechow et al., 2010). To date, the literature does not explain how firms might manage earnings when firms are considered to be interconnected. The scant knowledge about network-based approach to earnings management particularly among interconnected firms, therefore, makes our study relevant within the broad earnings management literature.

\section{Conceptual Framework}

\subsection{Evolution of Network Theory}

Herbert Simon did a classic study "The Architecture of Complexity". Building upon a wide spectrum of systems thinking from the physical sciences, biological sciences and social sciences, Herbert Simon (1991) evaluate the resilience and evolution of complex systems. To summarise, Simon (1991) show that complexity in a system is explained in terms of hierarchy or hierarchical systems. By hierarchy, he meant a system composed of interrelated subsystems with each subsystem being composed of interrelated subsubsystems until we reach the lowest level of subsystem with the most basic or simple structure (paraphrased). On theoretical grounds, Herbert show that complex systems evolve from basic simplicity into hierarchies (that is, interrelated subsystems) and each hierarchy has a near-decomposability property. A near-decomposability property implies that each subsystem can be decomposed into its smallest and basic structure to make it easier to understand how the complex system evolved, and to understand the dynamics of the complexity in the system.

\subsection{Network Typology and Complexity}

3.2.1. Network Typology "Networks are defined by a pair of sets (N, E) that stand for the finite set of nodes $\mathrm{N}=\{1,2,3 \ldots \mathrm{n}\}$, and $\mathrm{E}$ is a set of edges" (Markose, 2012, p.633). Networks are simply interconnected nodes where nodes stand for entities such as firms while the edges or connective links in the network represents contractual flows of claims and obligations among firms in the network. Similarly, in financial networks, nodes stand for financial entities such as banks, other financial intermediaries, and their non-financial customers and the edges or connective links represent contractual flows of liquidity 
and/or obligations to make payments and receive payments (Markose, 2012 paraphrased). Networks are interconnection between two or more nodes such that the presence of networks in a system is captured by the interdependence of two or more nodes on each other. ${ }^{5}$ Over time, networks grow and become complex. By complex, we mean the interconnection between nodes (firms) will grow and the interaction between them will become complex over time due to increasing volume of financial claims and obligations ${ }^{6}$ among firms in the network, and financial obligations or claims refer to the formal and/or informal contract that binds two or more counterparties in a financial transaction to fulfil the terms of the contract. ${ }^{7}$ In a nutshell, networks represent the interconnection of financial and non-financial obligations or claims across firms in a connected system and these obligations and claims across firms will grow, over time, and become complex. So, what is complexity?

\subsubsection{Complexity}

Jepson (2001) define complexity as the property of a model that makes it difficult to formulate its overall behaviour in a given language, even when given reasonably complete information about its components and their interrelations. ${ }^{8}$ In banking regulation, for instance, the complexity of the financial system that led to the 2007 to 2008 financial crisis arose mainly from the ambiguous securitisation activities of financial and non-financial institutions with each other. While complexity can be reduced to its most basic form if complexity can be quantified, however, the science of quantifying the complexity of financial systems is often difficult. To reduce complexity in a highly-connected (or complex) network, the starting point is to first identify the simplest structure in the network. In financial networks, for instance, the simplest structure in any complex financial system/network is the flow of obligations or claims between two firms: firm A and firm B. Over time, firm A will enter into contractual transactions that yield claims and obligations with other firms and the latter will enter into similar or dissimilar contractual obligations with other firms in the system until each firm becomes linked to one another by claims and obligations they did not directly engage in. This process continues until each firm become highly-interconnected (via networks) to other firms in the system. This describes how complexity builds up into the system, leading to complex interconnection among firms. ${ }^{9}$

\footnotetext{
${ }^{5}$ Networks also have wide applications in several field of study. In sociology, for instance, social network theory explains the behaviour of agents in complex systems in the sense that individuals are embedded in thick webs of social relationships and interactions, and autonomous individuals are able to work together to create an enduring and well-functioning society (see Freeman et al, 1979; Borgatti et al, 2009). In strategic management and organisational studies, the concept of networks shows the interaction within and between organisations as well as the interaction of organisations with the open environment (see Thorelli, 1986; O'Reilly and Finnegan, 2010). In the marketing discipline, the concept of networks is used to analyse product adoption decisions (see Aral and Walker, 2011; Choi et al, 2010). In the industrial organisation literature, the concept of networks is used to explain the behaviour of research and development expenditure (see Goyal and Moraga-Gonzales, 2001; König et al, 2012). In the economics and finance, the concept of networks is employed to understand financial contagion among financial institutions (see Von Peter, 2007; Soramaki et al, 2007).

${ }^{6}$ Flow of payments, for example in financial firms, represent obligations or claims such as credit default swaps, letters of credit, negotiable certificate of deposits, loans, etc.

${ }^{7}$ Gai et al (2011) view financial networks as consisting of a number of banks randomly interlinked by their claims on one another with each bank represented by a node on the network.

${ }^{8}$ From a sociology perspective, complexity may arise from the interaction among multiple actors (individuals, organizations, etc.) which leads to the emergence of patterns that makes it difficult to predict behaviour even when the simple and basic rules of interaction are known.

${ }^{9}$ For banks, for instance, Shin (2009) points out that securitisation activities by banks increased the complexity
} 


\subsection{Contagion and Networks}

Contagion in networks can occur when unexpected, abnormal and severe shock to the system spreads across fragile networks such that if the shock leads to the failure of one firm, the likelihood of failure of other firms connected to it increases. For instance, in financial networks, Freixas et al (2000) and Brusco and Castiglionesi (2007) show that higher levels of interconnection among firms improves the resilience of financial networks to withstand financial contagion. ${ }^{10}$ They argue that higher interconnection in networks improves risk-sharing among firms in the network by easily absorbing shocks when they occur, however, higher-interconnection in networks can also lead to contagion because shocks spread quickly in a web of highly-interconnected networks. Also, the rate at which contagion spreads depend largely on how quickly agents (or firms) in the network react to information particularly bad news (see. Castiglionesi, 2007). Therefore, in a complex network, contagion convey the idea that the failure of an interconnected firm to meet its obligation will send shocks that trigger panic to other firms connected to it, implying that contagion spreads quickly in highly connected networks.

\subsection{Firm's positioning in a Complex Network}

A complex network has a core (inner) periphery and a non-core (outer) periphery, and this fact has been articulated by several studies that examine financial networks (see. Soramäki et al, 2007; Inaoka et al, 2004; Boss et al, 2004, etc.). Firms in the core periphery are highly inter-linked by claims and obligations of multiple counterparties (i.e. other firms) in the system relative to firms in the outer periphery, implying that firms positioned in the outer periphery in a complex network have lesser interconnection (i.e., flow of claims and obligation) with other firms while firms positioned in the inner core periphery have more complex interconnection (flow of claims and obligations) with other firms in the network. Allen and Babus (2008) posit that firms (banks) at the core periphery perform better than firms (banks) in the outer periphery because certain network structures bring some benefits that well-positioned firms (banks) in the network are able to exploit to take full advantage of such benefits. Hochberg et al (2007) examine venture capital firms that are interconnected by a network of syndicated portfolio company investments. They find that better-networked venture capital firms have

\section{Network-Based Earnings Management Framework}

So far, there is yet no literature that explains managerial financial reporting discretion among firms that are considered to operate as interconnected networks. Also, the literature is relatively silent about the financial reporting behaviour of agents (managers of firms) in the network. In this section, we analyse the

\footnotetext{
of the financial system by lengthening the intermediation chain (or networks) in the financial system just before the 2008 financial crisis began. The magnitude of the 2008 financial crisis revealed how fragile the global financial network was, at that time.

${ }^{10}$ The use of a network approach to understand the financial contagion among financial institutions across several countries became more pronounced in the literature after the 2008 financial crisis (see Garratt et al, 2011; Kubelec and Sa, 2012; Glasserman and Young, 2015; Gai et al, 2011), while the use of network topology to study financial contagion is at its infancy in the economics and finance literature (Haldane and May, 2011), and the network typology is relatively silent about the behaviour of agents in the network (Gai et al, 2011).
} 
possible financial reporting behaviour of managers of interconnected firms. To begin, we make some assumption $^{11}$, and we assume that these propositions hold true.

\subsection{Assumptions}

1. There are firms in an endogenous network.

2. Over time, the network evolves from a simple structure to a more complex structure consisting of a core (inner) and non-core (outer) periphery, implying that there are firms in the core (inner) periphery and firms in the non-core (outer) outer periphery.

3. Every firm is connected to at least one firm, and the manager of each firm is aware of the interconnection between his firm and other firms connected to it, and the manager is also aware of the interaction among them.

4. To participate in the network, firms will anticipate the costs and benefits of participating in the network and make a decision to join or not to join. This implies that managers will undertake some cost-benefit analysis of interconnections with other firms. Also, firms that have existing connections with other firms will continuously re-evaluate the cost and benefit of their existing connection to make a 'remain or disconnect' decision.

5. Managers of firms in the network are highly sensitive to the actions of firms that are most interconnected to them and are less sensitive to the actions of firms that are less connected to them.

6. A highly-connected firm in a network will take actions to ensure the survival and stability of the firm if such action leads to the survival and stability of other firms connected to it since its survival depends on the survival of others. Interconnected firms whose survival depends on the stability of the entire system will have strong incentive to pursue stability objectives rather than engage in aggressive competition. However, if there is competition among interconnected firms, competition in the network will motivate interconnected firms (and their managers) to take actions that will make their firm appear stable to avoid losing their connection with valuable firms who are quick to de-link themselves from 'distressed' or 'unstable' firms, as a competitive strategy.

7. Managers in the network have discretion to adopt certain accounting techniques in financial reporting, and the choice of accounting technique adopted by a manager may depend on the accounting technique adopted by other firms in the network.

8. Regulators are aware of the network-like structure among firms in the industry

9. The objective of regulation introduced by industry regulators in complex networks or systems is to ensure stability in the network-system and to ensure the resilience of the network.

Managers of firms in the core periphery of the network will have incentives to take actions that promote the stability and survival of the firm as well as the survival of other firms connected to it if the manager believe that the firm's survival is linked to the survival of other firms in the interconnected system despite the competition among firms in the system. Similarly, firms in the noncore (outer) periphery that are

\footnotetext{
${ }^{11}$ Every framework and/or theory in every discipline has some underlying assumptions
} 
connected to firms in the core periphery will take similar or dissimilar actions to promote their survival and stability in the interconnected system as well. Even in the absence of shocks that propagate contagion in the network, managers of firms in the core-periphery will take actions that ensure, and reinforce, the stability and survival of the firm and other firms connected to it.

One simple way to improve the survival and stability of firms in the core-periphery is to ensure that such firms remain profitable which can be achieved through income-increasing or income-smoothing or lossreducing strategies. This is because managers of firms in the core-periphery understand that reporting losses sends a bad signal to other firms connected to it, and managers of such firms will seek to avoid sending such bad signal. Hence, these managers will have some incentive to use accounting (and nonaccounting) techniques to manage reported earnings to improve the firm's profitability and performance. By remaining profitable, the risk of panics and shocks that amplifies contagion following the reporting of unexpected and massive losses, is reduced significantly. Moreover, when multiple firms in the core periphery use accounting and non-accounting techniques to alter earnings to appear profitable or to appear stable, there will be a complex web of earning management activities going on in the network aimed at improving the stability position or profitability of firms in the core periphery in the network.

Furthermore, managers of firms in the core periphery will pay close attention to how their earnings management choices affects the balance sheet of firms that are closely connected to them ${ }^{12}$ - that is, other firms that hold majority of the firm's (financial and non-financial) claims as well as firms it owe most (financial and non-financial) obligations. For instance, when interconnected firms report significant losses, such losses could send a signal that firms in the core periphery are gambling with the claims of firms connected to them. In response to this, counterparty firms may decide to either (i) change their earnings management practices to reduce the impact of counterparty risk on their balance sheet; or alternatively, (ii) counterparty firms could sever or eliminate their link from firms in the core periphery before contagion spreads. On the other hand, managers of firms in the core periphery are less likely to take into account the impact of their earnings management practices on the balance sheet of firms in the outer periphery in the network-system.

\subsection{Regulated Networks and Income Smoothing.}

In regulated networks ${ }^{13}$, regulators aim to promote the stability of firms in a networked-system. One way regulators can achieve this objective is to monitor closely the behaviour of firms in the core-periphery in the network-system. Regulatory pressure on firms in the core periphery will compel managers of such firms to adopt earnings management techniques that align their behaviour with the stability objectives of regulators who want to promote stability in the networked-system; therefore, the desirable earnings management technique is one that helps to stabilise the system and improve the resilience of the network. Of all the common earnings management techniques, one common form of earnings management linked to firm stability and the stability of the overall system is 'income smoothing'. Income smoothing practices allow managers to smooth earnings over time by reducing too high earnings and increasing too low

\footnotetext{
${ }^{12}$ This view goes contrary to the classic view that firms compete against each other. Rather, we argue that this will not be case if firms exist in a system where firms understand that the collapse of a highly-connected firm can lead to the collapse or near-collapse of other firms connected to it, directly or indirectly.

${ }^{13}$ Given that regulators are aware that the system has evolved into a complex network, one objective of regulation in complex and fragile networks would be take steps that promote overall stability in the networksystem.
} 
earnings so that reported earning is never too high or too low. Income smoothing may take the form of income-decreasing earnings management to lower excessive profit or may take the form of incomeincreasing earnings management to increase too-low profit, so that reported earnings are never too high or too low to avoid sending unintended signals to counterparties. Further still, the incentive to smooth income may be driven by explicit contracts ${ }^{14}$ and managerial opportunistic ${ }^{15}$ behaviour. In networks, the incentive to smooth income may also be influenced by (i) the position of the firm in the network and (ii) the centrality of the firm in the network. By position of the firm, we mean the exact position or location of the firm in the network: either at the inner core periphery or at the outer periphery. By network centrality, we mean the degree of interconnection of a firm relative to other firms - some firms are more interconnected than others.

\subsubsection{Network Centrality and Income Smoothing}

Network centrality refers to the degree of interconnection of a firm relative to other firms in the network some firms are more interconnected than others. We propose that the extent of income smoothing practice in complex networks is positively related to the centrality of firms in the network-system. This is because when a firm becomes increasingly central to the system due to its extensive interconnection with multiple firms, regulators will increase its scrutiny and monitoring of highly interconnected firms in the core periphery. To avoid such scrutiny and monitoring, firms in the core periphery will prefer to use accounting techniques to smooth profits over time because income smoothing promotes firm stability, promotes the stability of the network/system and it align with the stability objectives of industry (or network) regulators ${ }^{16}$. Although some regulators can see through income smoothing (mainly, accrualbased income smoothing) ${ }^{17}$, regulators may not take actions against highly-connected firms that smooth income because such income smoothing behaviour aligns with the stability expectation of industry supervisors/regulators. Overall, the main argument here is that firms in the inner core of an interconnected and regulated network-system are more likely to rely on income smoothing behaviour as a preferred form of earnings management.

\subsubsection{Trade-off: Earnings Management Choices versus Network Centrality.}

Apart from income smoothing, there are other earnings management alternatives available to managers of firms in the core periphery of the network-system. However, the earnings management techniques that managers of firms in the core periphery can adopt should decrease as the firm's network-centrality increases in the networked-system. This is because, as the network centrality of a firm increases in a regulated network-system, the manager will narrow his earnings management strategies to strategies that stabilise firm performance over time particularly when managers anticipate shocks to the system that might affect the firm, and when managers anticipate (and want to avoid) the negative publicity that follows fault-finding by regulators. On the other hand, the earnings management techniques available to managers of firms with lower network-centrality increases as firms' network-centrality decreases in the network-system because the actions of the managers of such firms are less likely to pose any significant

\footnotetext{
144 Such as: the need to receive bonus plans, avoid debt-covenant violation, avoid the political cost of reporting too high profits

${ }^{15}$ For example, the need to save the managers' job, etc

${ }^{16}$ See Assumption 9

${ }^{17}$ Cohen and Zarowin (2008) show that regulators can see through accrual based earnings management compared to real earnings management, and accruals reverse over time.
} 
systemic concern to the stability of the entire network-system partly because they are connected by fewer claims compared to firms in the core periphery of the network-system. Hence, managers of firms with low network centrality will have more opportunity to use a wide range of earnings management strategies because they face less scrutiny by regulators; therefore, managers of such firms are not constrained to rely solely on income smoothing techniques although it is also an available option to them. From the reasoning above, two premise can be drawn. One, there is an inverse relationship between a firm's network centrality and the number of earnings management techniques the firm manager can adopt in a regulated network-system. Two, there is a positive relationship between a firm's network centrality and the propensity to use income smoothing strategies in regulated networked-systems, assuming regulators/supervisors are concerned about the stability of the networked-system.

\subsection{Why Core-periphery Firms Smooth Income}

\subsubsection{Maintain Implied Reputation}

We have established that, over time, the concentration of financial and non-financial claims and obligations around fewer firms give rise to 'highly-connected firms', and these firms are located in the core periphery of a network-system. However, interconnectedness can have implication for reputation. The concentration of claims and obligations around these few firms may signal that firms in the core periphery have had a long standing reputation of honouring their obligations and claims over the years and, therefore, many firms are willing to do business with firms in the core periphery, which further increases their network connectivity and their network centrality in the system. A manager's awareness of his firm's 'too-interconnected' position in the network/system can be a source of reputation to the firm, and the manager can have strong incentives to engage in income smoothing practices to maintain the firm's reputation in the network-system. For instance, the manager of a firm in the core periphery can anticipate that reporting significant losses or significant shortfall in earnings would send a bad signal (or bad news) to its counterparties and erode the confidence of counterparties in doing business with the firm, therefore, the manager will have incentives to smooth earnings upward to avoid reporting losses which helps them to avoid reporting bad news and to reassure counterparties of the firm's commitment to meet its obligations, thus, reinforcing its reputable position (or centrality) in the network-system.

\subsubsection{To Avoid Regulatory Scrutiny}

In a network-system where firms have a history of circumventing regulations and regulators are keen on fault finding, managers of firms in the core periphery will prefer to smooth income to avoid excessive scrutiny by firm regulators and to avoid attracting political noise to the firm. For instance, a firm that reports high profits may face backlash from the general public. The general public may protest against the firm's huge profit claiming that customers (or depositors, in the case of banks) were exploited. Such claim could attract negative commentaries from several interest groups including human rights activists, anticorruption groups and politicians. Politicians, in response, will pressure industry regulators and supervisors to thoroughly scrutinise the accounting numbers of firms in the core periphery. Because such scrutiny is costly to firms in the core periphery, such firms may take actions to avoid this cost. One of such action is to smooth their profits, that is, to make earnings not too high not too low. On the other hand, firms in the outer periphery may also smooth profits to avoid excessive regulatory monitoring but the extent of income smoothing will be higher for firms in the core periphery compared to firms in the 
outer periphery because firms in the outer periphery face less scrutiny from regulators compared to firms in the core periphery.

\section{Conclusion}

This article presents a perspective on earnings management in interconnected networks. We employ network typology to provide insights into the earnings management behaviour of firms in interconnected network-systems. We propose a network-based earnings management framework, and argue that (i) firms in the core periphery of an interconnected and regulated network-system are more likely to rely on income smoothing behaviour as a preferred form of earnings management because it promotes firm stability, the stability of the network-system and it aligns with the stability objectives of industry regulators. Also, we propose and argue that there is an inverse relationship between a firm's network centrality and the number of earnings management techniques a manager can adopt when firms are in a regulated network-system. Further, we propose and argue that there is a positive relationship between a firm's network centrality and the propensity to use income smoothing strategies when regulators are concerned about the stability in the network-system. Also, the framework demonstrates that firms in the core periphery may smooth income to maintain their reputation and/or to avoid excessive regulatory scrutiny. For policy purpose, the perspective we provide in this article can help regulators to better understand the earnings management practices of systemic (or highly-interconnected) firms. Insights from the proposed framework in this article may guide and inform future standard-setting policies on the financial reporting behaviour of systemic firms both in the financial and non-financial sector. Finally, one limitation of using network-based frameworks to understand managerial behaviour, for instance earnings management, is that it ignores the conflict of interest between boards and managers. Secondly, while the framework we adopt in this article argues that the extent of earnings management differs between firms in the core and outer periphery in a network, it does not specify whether the preferred earnings management strategy in networks are accrual-based or real activity-based, that is, it is not clear whether income smoothing behaviour of firms in the core periphery of a network is accrual-based or real activity-based. Future research can provide some insight into these issues.

\section{Reference}

Allen, F and Babus, A. (2008). Networks in Finance. Wharton Financial Institutions Center Working Paper No. 08-07. Available at SSRN: http://ssrn.com/abstract=1094883 or http://dx.doi.org/10.2139/ssrn.1094883.

Allen, F and Gale, D (2000), 'Financial contagion', Journal of Political Economy, Vol. 108, pages 1-33.

Acemoglu, D., Ozdaglar, A., \& Tahbaz-Salehi, A. (2013). "Systemic risk and stability in financial networks, No 18727”. National Bureau of Economic Research.

Acemoglu, D., Ozdaglar, A., \& Tahbaz-Salehi, A. (2015). Systemic risk and stability in financial networks. The American Economic Review, Vol 105 No.2, pp. 564-608.

Acharya, V., \& Richardson, M. (Eds.). (2009). "Restoring financial stability: how to repair a failed system, Vol. 542. John Wiley \& Sons. 
Afonso, G., Kovner, A., \& Schoar, A. (2011), "Stressed, not frozen: The federal funds market in the financial crisis". The Journal of Finance, Vol. 66 No. 4, pp. 1109-1139.

Amini, H., Cont, R., \& Minca, A. (2016), "Resilience to contagion in financial networks", Mathematical Finance, Vol. 26 No. 2, pp. 329-365.

Aral, S., \& Walker, D. (2011), "Creating social contagion through viral product design: A randomized trial of peer influence in networks”, Management Science, Vol. 57 No. 9, pp. 1623-1639.

Barth, M.E. and Gómez Biscarri, J and Kasznik, R and López-Espinosa, G, (2016), "Bank Earnings and Regulatory Capital Management Using Available for Sale Securities". Available at SSRN: https://ssrn.com/abstract=2448482 or http://dx.doi.org/10.2139/ssrn.2448482

Barth, M. E., Elliott, J. A., \& Finn, M. W. (1999), "Market rewards associated with patterns of increasing earnings", Journal of Accounting Research, Vol. 37 No.2, pp. 387-413.

Barton, J. (2001), "Does the use of financial derivatives affect earnings management decisions?" The Accounting Review, Vol. 76 No. 1, pp. 1-26.

Battiston, S., Gatti, D. D., Gallegati, M., Greenwald, B., \& Stiglitz, J. E. (2012), “Liaisons dangereuses: Increasing connectivity, risk sharing, and systemic risk", Journal of Economic Dynamics and Control, Vol. 36 No. 8, pp. 1121-1141.

Bergstresser, D., \& Philippon, T. (2006), “CEO incentives and earnings management” Journal of Financial Economics, Vol 80 No.3, pp. 511-529.

Boginski, V., Butenko, S., \& Pardalos, P. M. (2005). Statistical analysis of financial networks. Computational Statistics \& Data Analysis, Vol. 48 No. 2, pp. 431-443.

Borgatti, S. P., Mehra, A., Brass, D. J., \& Labianca, G. (2009), "Network analysis in the social sciences. Science, Vol. 323 No. 5916, pp. 892-895.

Boss, M., Elsinger, H., Summer, M., \& Thurner, S. (2004), "Network topology of the interbank market", Quantitative Finance, Vol. 4 No. 6, 677-684.

Bouvatier, V., Lepetit, L., \& Strobel, F. (2014), "Bank income smoothing, ownership concentration and the regulatory environment”, Journal of Banking \& Finance, Vol. 41, pp. 253-270.

Burgstahler, D., \& Dichev, I. (1997), "Earnings management to avoid earnings decreases and losses", Journal of Accounting and Economics, Vol 24 No 1, pp. 99-126.

Nagurney, A., \& Ke, K. (2001). Financial networks with intermediation. Quantitative Finance, 1(4), 441451.

Brusco, S., \& Castiglionesi, F. (2007), "Liquidity coinsurance, moral hazard, and financial contagion", The Journal of Finance, Vol. 62 No. 5, pp. 2275-2302.

Cabrales, A., Gale, D., \& Gottardi, P. (2015), "Financial contagion in networks", European University Institute, Working Paper, 1-27. 
Castiglionesi, F. (2007), "Financial contagion and the role of the central bank", Journal of Banking \& Finance, Vol. 31 No.1, pp. 81-101.

Castiglionesi, F., \& Navarro, N. (2008), “Optimal fragile financial networks”, Available at SSRN: http://ssrn.com/abstract=1089357

Choi, H., Kim, S. H., \& Lee, J. (2010), "Role of network structure and network effects in diffusion of innovations", Industrial Marketing Management, Vol. 39 No. 1, pp. 170-177.

Cohen, L. J., Cornett, M. M., Marcus, A. J., \& Tehranian, H. (2014), “Bank earnings management and tail risk during the financial crisis", Journal of Money, Credit and Banking, Vol. 46 No. 1, pp. 171-197.

Cohen, D. A., \& Zarowin, P. (2010), “Accrual-based and real earnings management activities around seasoned equity offerings", Journal of Accounting and Economics, Vol. 50 No.1, pp. 2-19.

Dechow, P. M., \& Shakespear, C. (2009), "Do managers time securitization transactions to obtain accounting benefits?” The Accounting Review, Vol 84 No.1, pp. 99-132.

Dechow, P. M., Myers, L. A., \& Shakespeare, C. (2010), "Fair value accounting and gains from asset securitizations: A convenient earnings management tool with compensation side-benefits". Journal of Accounting and Economics, Vol 49 No 1, pp. 2-25.

DeGeorge, F., Patel, J., \& Zeckhauser, R. (1999), "Earnings management to exceed thresholds", The Journal of Business, Vol 72 No. 1, pp. 1-33.

Freeman, L. C., Roeder, D., \& Mulholland, R. R. (1979), "Centrality in social networks: II. Experimental results", Social Networks, Vol. 2 No. 2, pp. 119-141.

Freixas, X., Parigi, B. and Rochet, J. C. (2000), “Systemic Risk, Interbank Relations and Liquidity Provision by the Central Bank", Journal of Money, Credit and Banking, Vol. 32, pp. 611-638.

Gai, P., \& Kapadia, S. (2010), "Contagion in financial networks". In Proceedings of the Royal Society of London: Mathematical, Physical and Engineering Sciences. The Royal Society.

Gai, P., Haldane, A., \& Kapadia, S. (2011), “Complexity, concentration and contagion. Journal of Monetary Economics, Vol. 58 No. 5, pp. 453-470.

Garratt, R.J., Mahadeva, L., Svirydzenka, K. (2011), "Mapping systemic risk in the international banking network". Working Paper 413, Bank of England, March.

Glasserman, P., \& Young, H. P. (2015). "How likely is contagion in financial networks?", Journal of Banking \& Finance, Vol. 50, pp. 383-399.

Gofman, M. (2017), "Efficiency and stability of a financial architecture with too-interconnected-tofail institutions", Journal of Financial Economics, Vol. 124 No.1, pp. 113-146.

Goyal, S., \& Moraga-Gonzalez, J. L. (2001), “R\&D networks”. Rand Journal of Economics, pp. 686-707.

Gunny, K. (2005,)"What are the Consequences of Real Earnings Management?” Working Paper, University of Colorado. 
Haldane, A. G., \& May, R. M. (2011), "Systemic risk in banking ecosystems. Nature, Vol. 469 No. 7330 , pp. 351-355.

Hribar, P., Jenkins, N. T., \& Johnson, W. B. (2006), "Stock repurchases as an earnings management device", Journal of Accounting and Economics, Vol. 41 No. 1, pp. 3-27.

Haldane, A. G. (2013). "Rethinking the financial network", pp. 243-278. Springer Fachmedien Wiesbaden.

Hochberg, Y., Ljungqvist, A. and Lu, Y. (2007), "Whom You Know Matters: Venture Capital Networks and Investment Performance”, Journal of Finance, Vol. 62, pp. 251-301.

Inaoka, H., Ninomiya, T., Taniguchi, K., Shimizu, T., \& Takayasu, H. (2004). "Fractal Network derived from banking transaction-An analysis of network structures formed by financial institutions". Bank of Japan Working Papers, 4.

Iori, G., De Masi, G., Precup, O. V., Gabbi, G., \& Caldarelli, G. (2008), “A network analysis of the Italian overnight money market", Journal of Economic Dynamics and Control, Vol. 32 No. 1, pp. 259278.

Jepson, E. J. (2001). "Sustainability and planning: diverse concepts and close associations", Journal of Planning Literature, Vol. 15 No. 4, pp. 499-510.

König, M. D., Battiston, S., Napoletano, M., \& Schweitzer, F. (2012). "The efficiency and stability of R\&D networks", Games and Economic Behavior, Vol. 75 No. 2, pp. 694-713.

Kubelec, C and Sa, F. (2012), "The geographical composition of national external balance sheets: 19802005, International Journal of Central Banking, Vol. 8 No. 2, pp. 143-189.

Lapointe-Antunes, P., Cormier, D., Magnan, M., \& Gay-Angers, S. (2006), "On the relationship between voluntary disclosure, earnings smoothing and the value-relevance of earnings: The case of Switzerland" European Accounting Review, Vol. 15 No. 4, pp. 465-505.

Leitner, Y. (2005), "Financial Networks: Contagion, Commitment, and Private Sector Bailouts", Journal of Finance Vol. 60, pp. 2925-2953.

Markose, S., Giansante, S., \& Shaghaghi, A. R. (2012), “Too interconnected to fail' financial network of US CDS market: Topological fragility and systemic risk", Journal of Economic Behaviour \& Organization, Vol. 83 No. 3, pp. 627-646.

Marquardt, C. A., \& Wiedman, C. I. (2004), "The effect of earnings management on the value relevance of accounting information”. Journal of Business Finance \& Accounting, Vol. 31 No. 3-4, pp. 297-332.

Nier, E., Yang, J., Yorulmazer, T., \& Alentorn, A. (2007) "Network models and financial stability", Journal of Economic Dynamics and Control, Vol. 31 No. 6, pp. 2033-2060.

O'Reilly, P., \& Finnegan, P. (2010), "Intermediaries in inter-organisational networks: building a theory of electronic marketplace performance”, European Journal of Information Systems, Vol. 19 No. 4, pp. 462480. 
Ozili, K.P. (2015), “Loan Loss Provisioning, Income Smoothing, Signaling, Capital Management and Procyclicality: Does IFRS Matter? Empirical Evidence from Nigeria", Mediterranean Journal of Social Science, Vol. 6 No. 2, pp. 224-232.

Ozili, K.P. (2017), "Discretionary Provisioning Practices among Western European Banks”, Journal of Financial Economic Policy, Vol. 9 No 1, pp. 109-118

Pincus, M., \& Rajgopal, S. (2002), "The interaction between accrual management and hedging: Evidence from oil and gas firms", The Accounting Review, Vol. 77 No.1, pp. 127-160.

Rangan, S. (1998), "Earnings management and the performance of seasoned equity offerings", Journal of Financial Economics, Vol. 50 No.1, pp. 101-122.

Roychowdhury, S. (2006), "Earnings management through real activities manipulation”, Journal of Accounting and Economics, Vol. 42 No. 3, pp. 335-370.

Sachs, A. (2014), "Completeness, interconnectedness and distribution of interbank exposures - a parameterized analysis of the stability of financial networks", Quantitative Finance, Vol. 14 No. 9, pp. 1677-1692.

Shin, H. S. (2009), "Securitisation and financial stability", The Economic Journal, Vol. 119 No. 536, pp. 309-332.

Simon, H. A. (1991), “The architecture of complexity” pp. 457-476. Springer US.

Soramäki, K., Bech, M. L., Arnold, J., Glass, R. J., \& Beyeler, W. E. (2007). The topology of interbank payment flows. Physica A: Statistical Mechanics and its Applications, Vol. 379 No. 1, pp. 317-333.

Sweeney, A. P. (1994), “Debt-covenant violations and managers' accounting responses”. Journal of Accounting and Economics, Vol. 17 No. 3, pp. 281-308.

Thomas, J. K., \& Zhang, H. (2002), “Inventory changes and future returns”, Review of Accounting Studies, Vol. 7 No. 2, pp. 163-187.

Thorelli, H. B. (1986), "Networks: between markets and hierarchies”, Strategic Management Journal, Vol. 7 No.1, pp. 37-51.

Von Peter, G. (2007), “International banking centres: a network perspective”. BIS Quarterly Review, Working Paper.

Zang, A. Y. (2011), "Evidence on the trade-off between real activities manipulation and accrual-based earnings management" The Accounting Review, Vol. 87 No.2, pp.675-703. 